\title{
NATIONAL WASTE TERMINAL STORAGE PROGRAM
}

PLANNING AND CONTROL PLAN

VOLUME I

MANAGEMENT SUMMARY

MAY 1977

"This report was prepared by Control Data Corporation, under subcontract 86Y-16535 with Union Carbide Corporation, Nuclear Division, under contract number W-7405-eng-26 with the Energy Research and Development Administration. The subcontract was administered by the Office of Waste Isolation, Union Carbide Corporation, Nuclear Division."

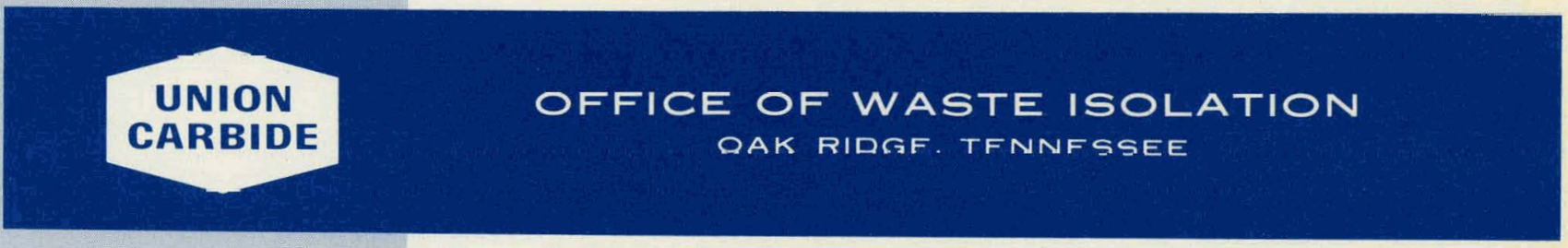

prepared for the U.S. ENERGY RESEARCH AND DEVELOPMENT ADMINISTRATION under U.S. GOVERNMENT Contract W-7405 eng 26 


\section{DISCLAIMER}

This report was prepared as an account of work sponsored by an agency of the United States Government. Neither the United States Government nor any agency Thereof, nor any of their employees, makes any warranty, express or implied, or assumes any legal liability or responsibility for the accuracy, completeness, or usefulness of any information, apparatus, product, or process disclosed, or represents that its use would not infringe privately owned rights. Reference herein to any specific commercial product, process, or service by trade name, trademark, manufacturer, or otherwise does not necessarily constitute or imply its endorsement, recommendation, or favoring by the United States Government or any agency thereof. The views and opinions of authors expressed herein do not necessarily state or reflect those of the United States Government or any agency thereof. 


\section{DISCLAIMER}

Portions of this document may be illegible in electronic image products. Images are produced from the best available original document. 
This report was prepared as an account of work sponsored by the United States Government. Neither the United States nor the Energy Research and Development Administration, nor any of their employees, nor any of their contractors, subcontractors, or their employees, makes any warranty, express or implied, or assumes any legal liability or responsibility for the accuracy, completeness or usefulness of any information, apparatus, product or process disclosed, or represents that its use would not infringe privately owned rights. 
This report was prepared as an account of work

sponered oy the United States Governmentes Energy

the United Development Administration, nor any of

their employoes. nor any of their contractors.

subcontractors. Of theis employes. ma any leget

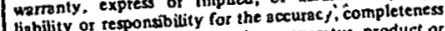

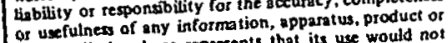

process disclosed, of represents

$Y / O W 1 / S U B-77 / 16535 / 1$

\section{NATIONAL WASTE TERMINAL STORAGE PROGRAM}

\section{PLANNING AND CONTROL}

\section{PLAN}

\section{VOLUME I}

\section{MANAGEMENT SUMMARY}

THE OFFICE OF WASTE ISOLATION

UNION CARBIDE CORPORATION-NUCLEAR DIVISION 
TABLE OF CONTENTS

Section

Page

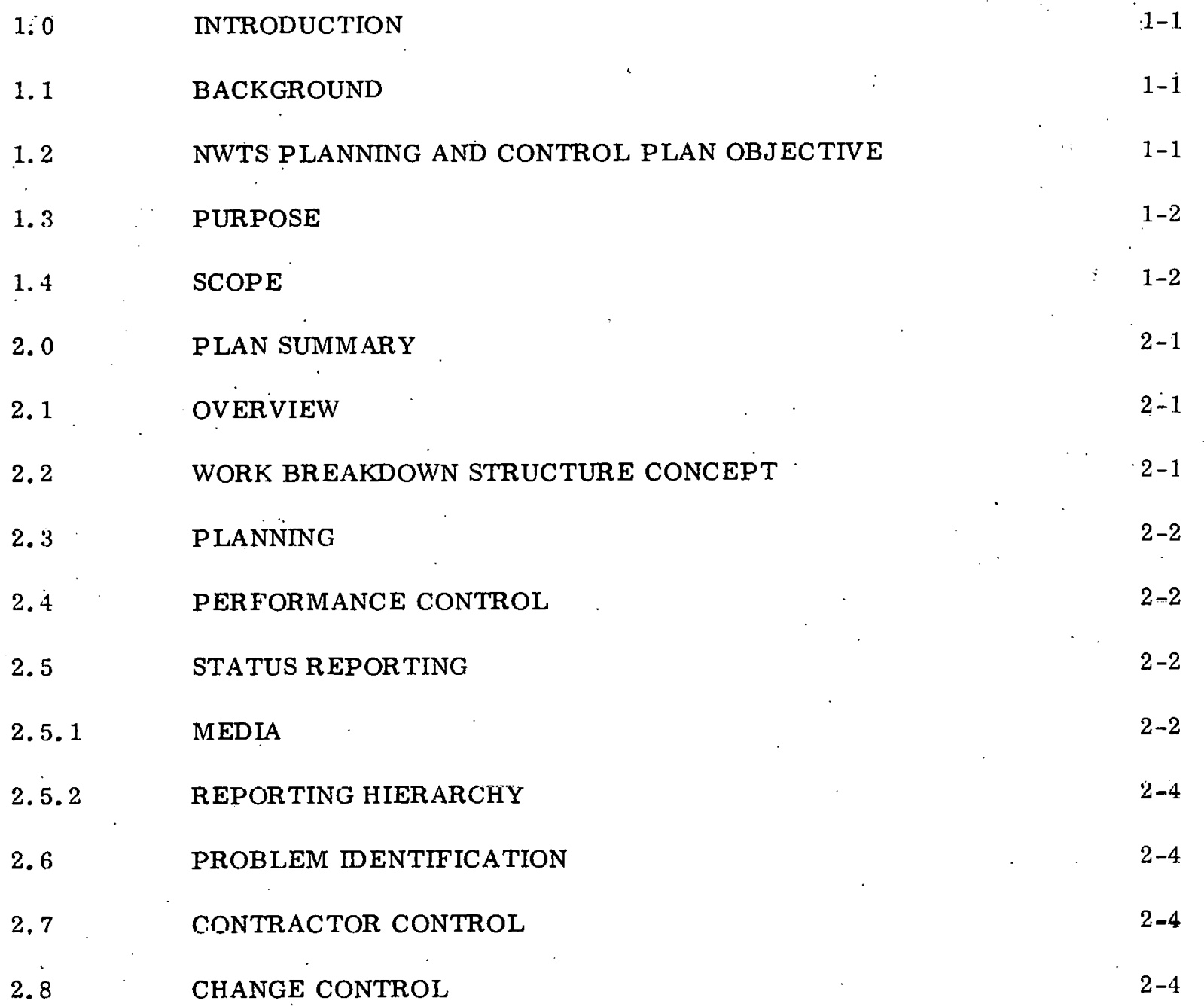


SECTION I

IN TRODUCTION

\subsection{BACKGROUND}

In May 1976, the Union Carbide Corporation - Nuclear Division (UCC-ND), at the direction of the Energy Research and Development Administration (ERDA) Division of Nuclear Fuel Cycle and Production (DNFCP), established the Office of Waste Isolation (OWI) to assume the responsibility for the National Waste Terminal Storage (NWTS) Program Management.

Upon assumption of the NWTS Program Management responsibility by OWI, it became evident that a Planning and Control system was integral to successful management of the NWTS Program. There were existing systems which were drawn upon in the formulation of the initial Planning and Control Plan. The ERDA Division of Reactor Development and Demonstration Performance Measurement System (RDD/PMS) was one of the principal source documents utilized in preparing the Planning and Control Plan.

\subsection{NWTS PLANNING AND CONTROL PLAN}

The objective of the NWTS Program Planning and Control Plan is to provide the information necessary for timely and effective OWI management decisions related to the NWTS Program including the formalized meohanisms for:

- Defining the NWTS program in a disciplined, structured manner from high-level summaries to discrete manageable work packages for which cost and schedule budgets can be established and performance responsibility assigned. 
- Providing program life cycle summary and detail, cost and schedule information to satisfy management requirements.

- OWI internal and contractor reporting which will provide the necessary information to quantify dollars expended and work accomplished in relation to planned expenditures and progress.

- Providing OWI management with program status in terms of summary and detailed cost and schedule information.

- Timely identification of problems for management resolution.

- Providing the information necessary to satisfy reporting requirements external to OWI.

\subsection{PURPOSE}

The purpose of the Planning and Control Plan is to describe the concepts and techniques that will be utilized by OWI to establish structured, completely planned and controlled technical, cost, and schedule NWTS baselines from which performance or progress can be accurately measured.

\section{4 SCOPE}

The provisions of the Planning and Control Plan apply to all OWI organizations and their contractors, sub-contractors, and suppliers as applicable. 
SECTION TWO

PLAN SUMMARY

\subsection{OVERVIEW}

The NWTS Planning and Control Plan will include the following program and project management techniques:

- Work Breakdown Structure (WBS)

- Planning (Schedules/Budget)

- Performance Control

- Status Reporting

- Problem Identification

- Contractor Control

- Change Control

\subsection{WORK BREAKDOWN STRUCTURE CONCEPT}

The WBS technique requires the identification of the major end items of the NWTS program with successive subdivision of each end item into increasingly detailed categories and subcategories of products and work. The completed WBS will define the total program effort in terms of manageable elements or packages of work which are the responsibility of the various 
OWI organizational entities. The WBS will then have identified the various levels and discrete elements of work to enable:

- The identification of any functional interfaces that might exist between the elements.

- The scheduling of tasks in logical sequence.

- The budgeting of tasks in logical sequence.

- The budgeting of funds in consonance with task schedules.

\subsection{PLANNING}

OWI will conduct the planning of the NWTS Program utilizing the WBS concept for an adequate definition of the work to be accomplished to develop schedules, budgets, and performance control. OWI has developed NWTS master schedules and associated budgets utilizing this technique. These schedules and budgets will be amplified and revised on a continuing basis as illustrated in Figure 2-1, Planning and Control Cycle.

\subsection{PERFORMANCE. CONTROL}

The fundamental elements of performance control for the successful management of a program are cost, schedule, and technical performance control. In the past, these parameters were controlled by a comparison of planned cost, schedule, and technical progress versus actuals. This basic technique has been enhanced by the "earned value" concept which will be utilized by OWI on the NWTS program.

\subsection{STATUS REPORTING}

\subsection{MEDIA}

The following media will be utilized by OWI managers and contractors as appropriate for reporting the status of the NWTS Program and the projects therein:

- Graphic Presentations

- Narrative Reports

- Program/Project Reviews. 


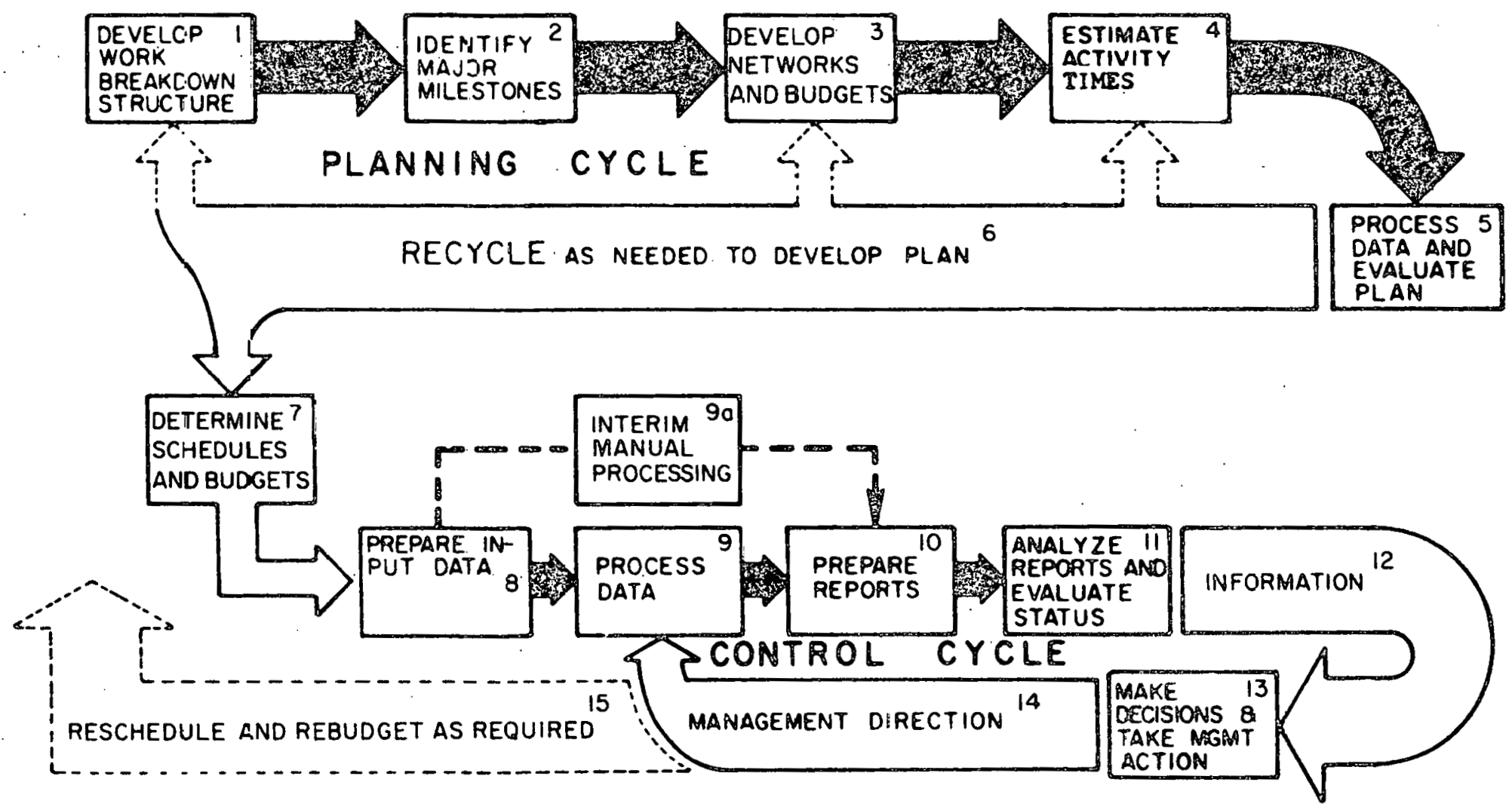

Figure 2-1. Planning and Control Cycle 


\subsubsection{REPOR TING HIERARCHY}

In ascending order, the reporting hierarchy commences with contractor reports to OWi. The next level of reporting is from OWI managers to the Director, OWI. Based upon information contained in contractor reports and the internal OWI reports, the Director, OWI reports externally to ERDA, UCC-ND, or other organizations as required.

\subsection{PROBLEM DENTIFICATION}

OWI managers will utilize the management by objectives and the management by exception techniques. OWI managers will establish variance tolerances for use by OWI management and contractors. When status reporting in the system's hierarchy indicates variances exceeding tolerances, a problem analysis report will be completed.

\subsection{CONTRACTOR CONTROL}

During the life cycle of the NWTS Program numerous contractors will be solicited to provide a great variety of services. In order that OWI can exercise sufficient control over contractor performance, it is mandatory that the individual contractor's planning and control systems be interfaced into the NWTS system.

\section{$2: 8$ CHANGE CONTROL}

All of the previous paragraphs in this section have described the concepts and techniques that will be utilized by OWI to establish structured, completely planned and controlled technical, cost, and budget NWTS Program baselines, from which performance or progress can be accurately measured. If the integrity of the system is to be maintained, any changes to the baselines must be incorporated in a disciplined manner. The eventual change control procedure will be an integral part of the NWTS Program Configuration Management Plan. 